\section{A road by any other name}

SIR - I agree with M. Benarie (Nature 376, 12; 1995) that famous British scientists are not as well known in Britain as are native scientists in other countries, but in London alone there are 16 roads named after Newton, 10 after Harvey, 6 after Haldane and 3 after Dalton. Even Bessemer and Flamsteed have been honoured. And Pasteur appears as a road name twice in the capital.

\section{Karl J. Hunter}

Flat 4, 11 Shakespeare Road,

Bedford MK4O 2DZ, UK

SIR - The Malpas area of Newport, Gwent, Wales, has Baird Close, Chadwick Close, Darwin Drive, Faraday Close, Haldane Place, Kelvin Close, Lister Green, Newton Way, Rutherford Hill, Trevithick Close and Whittle Drive, to give just a selection.

John Twin

The Patent Office,

6 Conde Close,

Ross-on-Wye,

Herefordshire HR9 5UR, UK

SIR - There is a Darwin Drive in Cambridge. Other roads in this city named after famous scientists include Cockcroft Place, Dalton Square, Davy Road, Newton Road, Rayleigh Close, Rutherford Road and Harvey Road.

P.-L. Chau

Department of Pharmacology,

University of Cambridge,

Cambridge CB2 1QJ, UK

SIR - In Ipswich (a town not noted for its academic links and unusual in that it still has no university), Lister, Kelvin, Rayleigh and Sherrington all have streets named after them and are within 400 metres of each other. Newton Street and Newton Road are in other parts of the town. In the humanities, Shakespeare, Arnold, Blake, Browning, Bunyan, Burns, Byron, Carlyle, Chaucer, Coleridge, Constable, Crabbe, Defoe, Dryden, Gainsborough, Garrick, Goldsmith, Kingsley, Kipling, Macaulay, Mitford, Thackeray and Wordsworth are also honoured.

John McCauley

29 Waverley Road,

Reading, Berkshire RG30 2QB, UK

SIR - In Bologna, where I was born, there is not only a via Isacco Newton but also a via William Shakespeare, a via Giorgio Byron and a via Carlo Dickens. Other streets, piazzas and avenues are named after other famous men of letters, as well as musicians, artists and other personalities of all sorts. Among scientists, there are streets named after Einstein, Copernicus, Galileo, Pasteur, Marconi and Fermi.
In contrast, the toponymy of British and American cities seems bland and sterile. Britain and the United States have no dearth of great men and women - they should have their place in the sun.

\section{Cesare Emiliani}

Department of Geological Sciences, University of Miami,

Coral Gables, Florida 33124, USA

SIR - M. Benarie, in trying to persuade the British to abandon the healthy habit of not naming streets after eminent people, quotes the Italian example. This is hardly commendable. We have had in recent history at least five waves of street name changes.

The Risorgimento and unity produced a vast shift from saints to Savoia royalty and Garibaldian characters, followed by re-namings to make room for the heroes and places of the First World War. Then came the turn of the Fascist martyrs and the like. The Second World War (and our skill in ending it as allies of our former enemies) and the civil war in northern Italy produced such a turmoil of changes as to to make the average Italian envious of the impersonal stability of the English street.

\section{Marco Fraccaro}

College Cairoli (formerly

Germanico-Ungarico),

27100 Pavia, Italy

\section{Birth dates}

SIR - Recent correspondence ${ }^{1-3}$ about the effects of birth dates on success in various sports prompted us to investigate birth dates of students entering Porto faculty of medicine in the past few years. People choose to study medicine for various different reasons, but in recent years students entering Portuguese medical schools have had one thing in common: they are among the most successful high school students. This is due to the scarcity of places in medical school compared with the number of interested candidates, and has resulted in the exclusion of any student with marks of less than 16-17 out of 20 in a series of cognitive tests.

Our analysis revealed an asymmetry of birth-date distribution, constant during the three-year period of study. The dates of birth of 263 medical students, compiled into quarters, are shown in the table $\left(\chi^{2}=16.437, P<0.001\right)$.

As can be seen, there is a significantly higher incidence of students born during the second trimester of the year. This distribution does not reflect any asymmetric distribution of births in Portugal during the years of 1973-75 when the students were born (detailed figures available from the authors on request).

A relative age advantage cannot be invoked to explain these data, as is sometimes done to explain success in sports ${ }^{1-3}$. We have no clear-cut answer, but the hypothesis considered self-evident by Michael Holmes ${ }^{4}$ to explain the relation-

\begin{tabular}{lcccc}
\hline \multicolumn{5}{c}{ PORTO FACULTY OF MEDICINE STUDENTS IN } \\
BIRTH-DATE QUARTERS \\
\hline Year of entry & Jan-Mar & Apr-Jun & Jul-Sep & Oct-Dec \\
$1991-92$ & 19 & 34 & 19 & 20 \\
$1992-93$ & 17 & 30 & 20 & 21 \\
$1993-94$ & 17 & 30 & 19 & 17 \\
Total & 53 & 94 & 58 & 58 \\
\hline
\end{tabular}

ship between season of birth and stance taken in two scientific revolutions by prominent scientists seems to be worth attention: seasons are experienced at different stages of early development, either indirectly through maternal behaviour and biology before birth, or directly in the first year of extrauterine life. During neurobiological development, "the brain must wire itself", , being very much dependent on external stimuli during critical periods of early life, so that kind of proposal makes real sense.

Isabel Azevedo

Perpétua Pinto-do-ó

Nuno Borges

Faculty of Medicine,

University of Porto,

4200 Porto,

Portugal

1. Dudink A. Nature 368, 592 (1994)

2. Edwards, S. Nature 370, 186 (1994).

3. Baxer-Jones A. \& Helms, P. Nature 370, 186 (1994).

4. Holmes, M. Nature 373, 468 (1995).

5. Stryker, M. P. Nature 375, 277-278 (1995).

\section{Down House}

SIR - "Down House - the birthplace of Darwin's theory of evolution by natural selection". Childhood home of the theory, maybe, but birthplace, no. The complete theory was surely born in late September 1838 on Marlborough Street in London, with the famous reading of Malthus, and the realization of the importance of competition among members of the same species ${ }^{2,3}$. The Darwins did not see Down House until July 1842 , and did not move into it until September 1842 (ref. 3) - four years after the theory's birth, and three months after Darwin had written out a brief rough draft of the theory.

\section{Alexander H. Harcourt}

Department of Anthropology,

University of California,

Davis, California 95616-8522, USA

1. Nature 375, 546 (1995).

2. Mayr, E. One Long Argument. Charles Darwin and the Genesis of Modern Evolutionary Thought (Harvard University Press, Cambridge, 1991).

3. Desmond, A. \& Moore, J. Darwin (Michael Joseph, London, 1991) 